DOI 10.37882/2500-3682.2021.06.17

\title{
БУНТ КАК КОНЕЦ РАБСТВА В ФИЛОСОФИИ А. КАМЮ
}

\section{REVOLT AS THE END OF SLAVERY IN THE PHILOSOPHY OF A. CAMUS \\ Salikh Aumed Khama-ali Salikh}

Summary: The article deals with the category of rebellion in the philosophy of A. Camus. Revolt, both metaphysical and political, is the only possible objection to the injustice of human destiny. The category of rebellion, according to $\mathrm{A}$. Camus, is closely related to the concept of fear. Man is viewed by Camus through a series of contradictions.

Keywords: revolt, metaphysical revolt, fear, human existence, rebellious person, political regime.

\author{
Салих Аумед Хама-али Салих \\ ФГБОУ ВО «Липецкий государственный \\ технический университет» \\ Omedhamaali@yandex.ru
}

Аннотация: В статье анализируется категория бунта в философии А. Камю. Бунт как метафизический, так и политический выступает единственно возможным возражением против несправедливости человеческого удела. Категория бунта, по А. Камю, тесно связана с понятием страха. Человек рассматривается Камю через ряд противоречий.

Ключевые слова: бунт, метафизический бунт, страх, человеческое бытие, бунтующий человек, политический режим.

экзистенциалы страха и угрозы смерти.

На первый взгляд может показаться, что страх и бунт несовместимы. Если страх мешает человеку бунтовать, то это означает, что человек страшится потерять свою неподлинную жизнь, свои привычные условия существования, источником которых является тирания. Это страх лишения установленного государственного порядка, который на самом деле есть воплощение произвола. В конечном счете разрушение такого порядка представляется им утратой сложившейся политической системы, которая погрязла в несправедливости, несмотря на то, что данная система грозит превратиться в фашизм или иную форму родовой тирании. С другой стороны, страх и бунт могут совпасть и находиться в гармонии, в той мере в какой страх выступает фундаментальной причиной бунта, в ситуациях, когда человек боится потерять жизнь в ее подлинном значении, страшится не быть свободным существом.

Раб, будучи несвободным человеком, бунтует против своего рабского положения и той системы, которая создала и поддерживает рабство. Посредством бунта он объявляет, что отрицает в себе раба, одновременно показывая, что не может больше терпеть унижения человека в своей жизни. Другими словами, это значит, что восставший индивид проводит границу между собой и остальными людьми, он выступает против вмешательства других в круг его личных прав. Отсюда можно сказать, что выделенный нами аспект страха не является полностью негативным, имея в виду страх как препятствие к бунту. В данном страхе вместе с тем кроются все те причины, которые служат исходным горючим материалом к началу бунта. Без этого позитивного аспекта страха невозможно преодолеть его негативную составляющую. Ведь тот, кто нечего не боится, может легко уничтожить все ценное, созданное человечеством. Тот 
же, кто боится всего, живет в вечном страхе, бежит от свободы и есть совершенный раб.

Восставший располагается как бы посередине этих двух крайних психолого-мировоззренческих позиций. Восставший не приемлет ни позиции полного отрицания страха в силу его отсутствия, ни позиции постоянного присутствия и культивирования страха. Бунт восставшего человека есть отрицание этих двух крайностей или двух аспектов бытия. Восставший не страшится столкнуться с теми трудностями, которые приносит с собой социальная свобода. Поэтому смерть для него выступает как личностная судьба. Одновременно восставший борется против нее, а фундаментальной линией защиты выступает у него поиск и утверждение истинного смысла и природы человеческого существования.

В рамках борьбы и противостояния у истинного восставшего всегда присутствует страх. И это не есть страх перед вечной борьбой человека в бытии, не боязнь муки и смерти, которые сопровождают борьбу. Это страх, прежде всего, потерять гармонию в отношениях человека с окружающим его социальным и природным миром.

Величие восставшего заключается в том, что он берет на себя большую ответственность. Бунтующий человек самый ответственный в отличие от правителей, которые часто выступают как самые безответственные люди. Во многих восточных странах можно и сейчас найти примеры неограниченной власти одного лица или группы лиц. Богатая история Востока может быть описана как история тирании и произвола. Тиран не знает и не желает признавать права другого человека. Он с радостью может мучить, изгонять или предавать смерти тех, кто, как он считает, не составляет славу его правящего двора.

Восставший - это человек, пробудившийся после ужасного сна, во время которого трудно разобрать, переживаем ли мы реальные события или все, что окружает нас есть лишь иллюзия. Политическая тирания возможна лишь при условии, когда люди сознательно принимают и поддерживают иллюзорную действительность, созданную вокруг них правящим сословием. Природа политической тирании такова, что отклоняет и принимает ничего нового в социально-политической, экономической, духовной сфере. Тирания создается на основе молчания и покорности.

Осознание и постижение причин отчужденности человека в социуме - это первый шаг к осознанию условий тирании. Это начало бунта, потому что осознание - это исходная форма протеста. Голос протестующего заставляет тирана прислушаться. А это уже настоящий бунт. Тирания - самая безухая политическая система, одна их худших форм правления, о которой говорили древние. В то время как все другие существующие политические режимы подчиняются закону постоянного движения, изменения, развития, тирания интерпретирует развитие как совершенствование ее собственного политического организма, что вовсе не предполагает его качественного изменения.

Человек может сберечь свое собственное бытие лишь при одном условии - это бунт, а в условиях тирании - это революция.

Конечно, в той мере, в какой существуют предпосылки для демократизации общества, в той же мере имеются предпосылки для тоталитаризма. Такая возможность существует сейчас в большинстве стран Среднего Востока. Иногда за ширмой демократии скрывается ложное лицо тирании. Следует отметить, что тирания не способна долго скрывать своего подлинного лица, особенно, когда начинает угрожать свободное волеизъявление граждан. Можно сказать, что тирания загоняет человека в положение раба. Ее можно уподобить смертельной болезни, которая унижает личность и удерживает человека в постоянном страхе. Страх и тирания есть две стороны одного и того же явления; они не могут существовать друг без друга. Чтобы сохранить себя тирания опирается на страх своих подданных. Все формы страха предполагают наличие элементов тирании в обществе, за исключением одной формы страха - страха потерять свое личное достоинство.

Для того чтобы нормально существовать, человеку необходимо отрицать любой политический режим, который лишает человека его подлинности. Отрицание в данном случае есть выражение бунта. Как говорит А. Камю, «нет может означать - слишком долго я терпел» [2]. Это «нет» утверждает существование границы. Эта же идея предела обнаруживается в чувстве бунтаря, что другой «слишком много на себя берет», простирает свои права дальше границы, за которой лежит область суверенных прав, ставящих преграду всякому на них посягательству. Как следствие, порыв к бунту коренится одновременно и в решительном протесте против любого вмешательства, которое воспринимается как просто нестерпимое, и в смутной убежденности бунтаря в своей доброй воле, а вернее, в его впечатлении, что он «вправе делать тото и то-то». В ряде случаев категория «терпение» может быть отождествлено с терпимостью, это положительный контекст социальной действительности. Однако, вместе с отталкиванием чужеродного в любом бунте происходит полное и непроизвольное отождествление человека с определенной стороной его собственного существа. Здесь скрытым образом вступает в игру ценностное суждение, и столь спонтанное, что оно помогает бунтарю выстоять среди опасностей. До сих пор он по крайней мере молчал, погрузившись в отчаяние, вынужденный терпеть любые условия, даже если считал их глубоко несправедливыми. Поскольку угнетаемый молчит, люди 
полагают, что он не рассуждает и ничего не хочет, а в некоторых случаях он и вправду ничего уже не желает [2].

Как следствие, терпение приводит к тирании и рабству. Такое терпение создает условия, при которых отсутствует свобода личности, человек обречен на молчание и послу- шание. А это ничто иное, как рабство. А. Камю указывает, что история господина и тирана укоренена в глубоком прошлом. В тот момент, когда бунтующий человек говорит «нет», он завершает эту историю и открывает страницу новой истории. Без бунтующего человека вся история человечества предстает для нас как история тирании.

\section{ЛИТЕРАТУРА}

1. Горохов П.А. Некоторые мысли о философии Альбера Камю: научная статья доктора философских наук: [Электронный ресурс]// Оренбург. - Режим доступа: https://docviewer.yandex.ru/view/4678740/?page;

2. Камю А. Бунтующий человек. Философия. Политика. Искусство: Пер. с фр. [Электронный ресурс]// М.: Политиздат.- Режим доступа: https://imwerden.de/ pdf/camus_buntuyushhy_chelovek_1990.pdf;

3. Спыну Л.М. В поисках истины: философия «абсурда и свободы» А.Камю// [Электронный ресурс]// Вестник РУдН, серия Философия, 2012, № 3. - Режим доступа: https://cyberleninka.ru/article/n/v-poiskah-istinyfilosofiya-absurda-i-svobody-a-kamyu.

с Салих Аумед Хама-али Салих (Omedhamaali@yandex.ru).

Журнал «Современная наука: актуальные проблемы теории и практики»

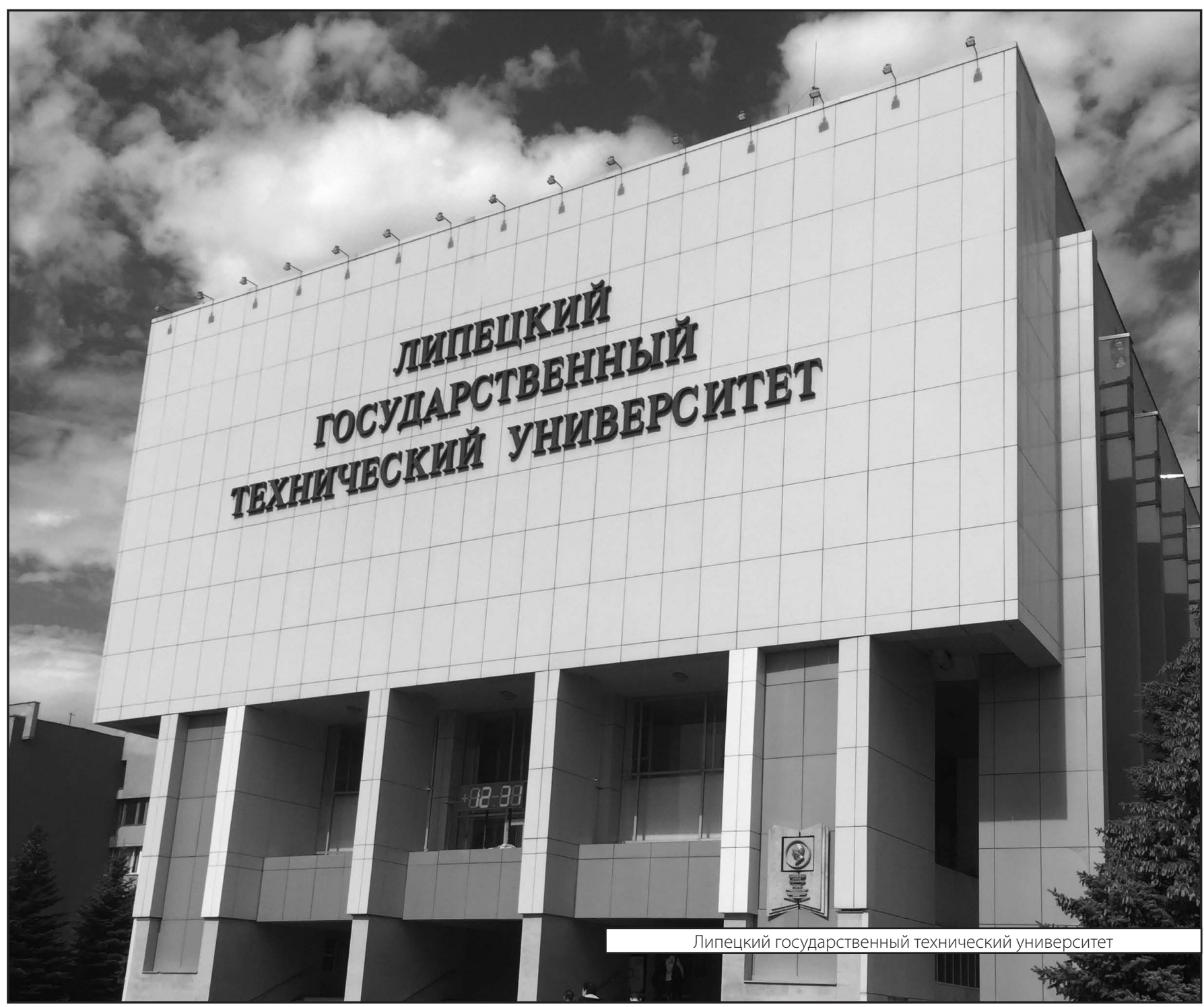

